\title{
With a little help from the state: interest intermediation in the domestic pre-negotiations of EU legislation
}

\author{
Gerald Schneider, Daniel Finke and Konstantin Baltz
}

\begin{abstract}
Theories of interest intermediation maintain that the formation of bargaining positions in the European Union follows a distinctive bargaining style. This article evaluates such claims empirically. It compares the predictive accuracy of Nash bargaining models which take the salient features of five types of interest intermediation into account. We show that the interaction between government agencies, interest groups and parties in the formation of EU legislation is largely étatiste. When important private interests are at stake, the pattern is also quite often clientelistic or corporatist. The dominance of the state in the less politicized decision-making processes is apparent in all four countries under consideration: Finland, Germany, Great Britain, and the Netherlands. Consociationalist arrangements are rare in this arena of public policy-making.
\end{abstract}

KEY WORDS Applied bargaining theory; domestic politics; European Union; interest intermediation; Nash bargaining solution (NBS); model evaluation.

\section{INTRODUCTION}

Integration theorists have repeatedly clashed over the role that interest groups play in the process of European integration. Haas $(1958,1964)$ in particular argued that the activities of integrationist élites must be taken into account before co-operation can be realized. Sandholtz and Zysman (1989) demonstrated in this vein how multinational firms were pushing governments into the adoption of the 1992 programme. These rosy assessments are in considerable contrast to the negative effects that public choice scholars associate with interest groups. Gillingham (1991) has attributed the foundation of the European Coal and Steel Community to the protectionist wishes of the directly concerned cartelistic industries. In his history of the integration process, he laments the turn towards corporatist decision-making under the reign of Commission President Delors (Gillingham 2003).

Both the optimistic and the pessimistic assessments share the feature of being overly inductivist. This problem, however, plagues the literature on interest intermediation in general. As most contributions to this strand of research do not possess sound theoretical foundations, we do not really know how interest

Author Posting. (c) Taylor \& Francis, 2007.

This is the author's version of the work. It is posted here

by permission of Taylor \& Francis for personal use, not for redistribution.

The definitive version was published in Journal of

European Public Policy, Volume 14 Issue 3, April 2007.

doi:10.1080/13501760701243814

(http://dx.doi.org/10.1080/13501760701243814) 
groups and governments interact in European Union (EU) decision-making. ${ }^{1}$ Trying to fill this research gap to some extent, this paper attempts to uncover the structure of interest intermediation for a particularly under-studied decision-making arena - the domestic pre-negotiations that take place after the European Commission has introduced a new legislative proposal. We will examine the formation of the bargaining stances that governments advance during the deliberations of the Council of Ministers across 15 decisionmaking cases and four member states: Finland, Germany, the Netherlands and the United Kingdom.

According to a rich empirical literature, these states should follow a different logic of interest intermediation. While Great Britain is associated with pluralist competition between interest groups, continental states have traditionally been more selective in inviting private actors to the preparation of legislative projects (e.g. Siaroff 1999). Such classifications have also influenced the literature on interest intermediation in the EU. Most contributors to this line of research suspect that corporatist forms of interest intermediation should also unfold in the domain of EU policy-making (Grote and Schmitter 1999), while some researchers believe that consociationalism becomes increasingly relevant within the EU (Crepaz 2002, but see also Bogaards 2002).

The article takes issue with these claims and assesses whether corporatist, consociationalist, pluralist, étatiste and clientelistic models of interest intermediation can accurately predict decision-making outcomes. As the dominant decision-making mode within systems of interest intermediation is bargaining rather than voting, our evaluation relies on the Nash bargaining solution (NBS), a canonical tool in bargaining theory, as the unifying theoretical approach. We develop a series of NBS bargaining models that take the specific features of the ideal types of interest intermediation into account which we expand on after discussing the relevant literature. The comparative evaluation of the predictive accuracy of these models shows that the étatiste model is empirically the most precise approach across all four member states. The consociationalist model, in return, provides the most inaccurate forecasts at the average. More generally, the findings reveal that the state is the ultimate arbiter in the domestic pre-negotiations and that private actors only exert considerable influence in the more controversial cases.

\section{PATTERNS OF INTEREST INTERMEDIATION IN THE FOUR MEMBER STATES}

The literature on interest intermediation still follows the traditions inaugurated by Lehmbruch (1967) and Schmitter (1974). These authors pioneeringly maintained that the relationship between contending interest groups resembles corporatist rather than pluralist patterns of interaction in continental Europe. Although the empirical significance of this conjecture is not clear (Traxler and Knittel 2000), a considerable number of articles have analysed the causes 
and consequences of corporatist intermediation in Europe and beyond (Grote and Schmitter 1999).

The growing importance of the EU has affected this discussion in several ways. Most studies analyse the possible transformation of interest intermediation at the EU level (Andersen and Eliassen 1993; Greenwood and Aspinwall 1998; Mazey and Richardson 1993; Pedler and Van Schendelen 1994). Some studies contend that the EU increasingly shows corporatist features (Gorges 1996), while others believe that it is moving in a pluralist direction (Traxler and Schmitter 1995). Crombez (2002), by contrast, contends that no patterns should be recognizable in the aggregate because the preference profiles change from one decision-making process to another. This agnostic attitude has its predecessor in Freeman (1989). He cautioned that patterns of interest intermediation might be observable for sectors, but probably not for countries or, in our case, for a supranational entity like the EU.

Only a handful of studies examine how interest groups try to influence their governments at the domestic level (Van Schendelen 1993). Greenwood and Jordan (1993) believe that the national channel of influence is still dominant in Great Britain. Based on an extensive survey, Eising (2004: 236) contends that 'national and EU associations have established a pronounced division of labour among them'.

The conflicting conjectures and the varying empirical contexts of these studies make it quite hard to assess whether interest intermediation in the EU matches a specific pattern. A further problem for such an assessment is the profusion of competing definitions for the very same analytical category. This is most obvious for 'corporatism' and thus the concept that Lehmbruch and Schmitter had developed to understand business-labour interactions in continental Western Europe. In an encompassing evaluation, Siaroff (1999) has identified 22 'structures' that are supposedly characteristic of a corporatist political economy, and he evaluates the empirical significance of 23 competing rankings.

These qualifications have to be kept in mind for the attempt undertaken in this paper to test the predictive accuracy of different models of interest intermediation for the domestic pre-negotiations on EU politics. If we refer to the conventional distinction between 'corporatism' and 'pluralism' as a starting point for our inquiry, most observers agree that the four countries under examination should be classified differently. According to Siaroffs (1999) metaranking, the Netherlands is the most corporatist country, followed by Germany, Finland and the United Kingdom. ${ }^{2}$ The distinction between pluralism and corporatism does not, however, mirror the empirical reality of interest intermediation in any satisfactory manner. In an early contribution, Katzenstein (1985) pointed out that the interaction patterns between interest groups and the state can benefit one side more than the other. He particularly maintained in this vein that a corporatist system can be biased in favour of either labour or capital. We argue that clientelistic forms of interest intermediation would emerge in the event that this bias is complete. Our earlier empirical studies have shown that 
such extreme forms of favouritism often benefit producers' interests (Schneider and Baltz 2003). A final system of interest intermediation, which we will consider here, is étatisme, where only government actors influence the decisionmaking process. Again, actor-focused studies reveal that state actors are particularly important during the decision-making phase which we are studying here (Schneider and Baltz 2005). ${ }^{3}$

We will examine in the following whether such classification attempts are meaningful for the study of domestic pre-negotiations of the legislative projects that the EU pursues. To this end, Table 1 defines systems of interest intermediation across three dimensions. ${ }^{4}$ We distinguish first whether the power of the state vis-à-vis the interest groups is large or small. A similar distinction is made with regard to the question of whether or not an asymmetry of power can be observed between the competing interest groups. The final differentiation refers to the possibility that powerful actors collaborate rather than compete with each other.

The classification results in eight ideal types of interest intermediation. The top left-hand corner represents a situation in which the state co-ordinates its activities mainly with one sort of interest group. This category summarizes what Katzenstein (1985) has called liberal and social democratic corporatism. While Germany typically belongs to the former, the Scandinavian states including Finland are tendencially attributed to the latter category. The lower left-hand

Table 1 A classification of systems of interest intermediation

\begin{tabular}{|c|c|c|c|c|c|}
\hline & & & Power & of the state: & \\
\hline & & Large & & Smal & \\
\hline & & Co-ordinat & tion: & Co-ordin & nation: \\
\hline & & Yes & No & Yes & No \\
\hline בั: & $\begin{array}{l}8 \\
0 \\
0 \\
-1\end{array}$ & Biased corporatism & Clientelism & $\begin{array}{c}\text { Biased } \\
\text { consociationalism }\end{array}$ & Biascd pluralism \\
\hline 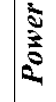 & 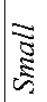 & Corporatism & Étatisme & Consociationalism & Pluralism \\
\hline
\end{tabular}


cell refers to systems where the state plays an active role and competing interests have a similarly large influence on policy outcomes. Although the category has been developed mainly for the interaction between capital and labour, 'corporatism' is the term to describe this sort of collusive behaviour. Clientelist modes of interaction occur if one interest group is stronger than another, if interest groups do not co-ordinate their activities and if one group receives more support from the state than the other. The only difference between this sort of interest intermediation in an étatiste system is that the state does not favour one particular interest group in the latter category. If the state is weak, the relevant interest groups dominate the networks of interest intermediation. A system is consociationalist if some co-ordination between interest groups occurs. Again, biased or balanced instances of consociationalist structures are possible. If there is competition between interest groups, we can speak more of a pluralist mode of interaction. Power asymmetries between competing interest groups lead to biased forms of competition in which, according to Olson (1965), 'privileged' interest groups overtake latent ones.

In the following, we will test whether specific patterns are recognizable in the decision-making cases examined here, and whether these domestic prenegotiations of EU legislation follow a particular, state-specific logic of interest intermediation. As the positions of the individual stakeholders are necessarily related to each other on a specific question and are thus never those independent observations that we need for a comparative inquiry at the actor level, we will focus on the issues under contestation rather than individual gains or losses. We will show in our empirical application how accurate the predictions of the final decision-making outcome are which can be deduced from the models of interest intermediation under scrutiny. The baseline for all competing models is the NBS (Nash 1950) which seems especially appropriate in light of the broad consensus that bargaining is the dominant decision-making mode in systems of interest intermediation (e.g. Lehmbruch 1976). ${ }^{5}$

\section{RESEARCH DESIGN}

To classify decision-making cases according to the prevailing mode of interaction, we resort to the National Decision-Making in the European Union (NDEU) dataset. This dataset contains detailed information on 15 legislative proposals that the European Commission initiated and which were submitted to the member states for consideration between 1997 and 1999. The NDEU cases refer to a larger sample of around 70 legislative proposals fully analysed in Thomson et al. (2006) and Stokman and Thomson (2004). The 15 proposals we examine here cover very different policy areas, from health over consumer to fishery policy. Table 2 lists the cases examined here and shows, furthermore, differences in the number of contested issues that these proposals created, the number of actors and the variance of the policy positions.

We relied on expert interviews and secondary sources to gather the decisionmaking data. Four collaborators were sent, after initial inquiries about the 
Table 2 A comparison of the proposals across four countries

\begin{tabular}{|c|c|c|c|c|c|c|c|c|c|c|c|c|c|c|c|}
\hline \multirow[b]{2}{*}{ Proposal } & \multicolumn{5}{|c|}{ Number of issues } & \multicolumn{5}{|c|}{ Number of actors ${ }^{1}$} & \multicolumn{5}{|c|}{ Standard deviation } \\
\hline & $D$ & Fin & $N L$ & UK & $\varnothing$ & $D$ & Fin & $N L$ & UK & $\varnothing$ & $D$ & Fin & $N L$ & UK & $\varnothing$ \\
\hline End-of-life vehicles & 2 & 1 & 1 & 5 & 2.3 & 13 & 6 & 6 & 7 & 8 & 37 & 41 & 34 & 47 & 40 \\
\hline Taxation on savings income & 3 & 3 & 3 & 5 & 3.5 & 5 & 6 & 5 & 18 & 8.5 & 39 & 44 & 46 & 44 & 43 \\
\hline Taxation of cigarettes & 2 & 1 & 2 & 1 & 1.5 & 5 & 2 & 4 & 5 & 4 & 46 & 71 & 47 & 45 & 52 \\
\hline Supervision of e-money & 1 & 3 & 3 & 0 & 1.8 & 4 & 5 & 5 & - & 4.7 & 50 & 42 & 48 & - & 47 \\
\hline Notification agreements & 3 & 3 & 5 & 2 & 3.3 & 6 & 8 & 8 & 10 & 8 & 40 & 42 & 43 & 40 & 41 \\
\hline Legal aspects of e-commerce & 3 & 4 & 2 & 2 & 2.8 & 17 & 9 & 7 & 11 & 11 & 30 & 39 & 32 & 43 & 36 \\
\hline Prevention/Control of TSE* & 1 & 1 & 3 & 0 & 1.3 & 9 & 13 & 6 & - & 9.3 & 38 & 8 & 39 & - & 28 \\
\hline Limits vet. medical products & 0 & 0 & 4 & 0 & 1.0 & - & - & 9 & - & 9 & - & - & 39 & - & 39 \\
\hline Establishment of 'Eurodac'** & 1 & 0 & 3 & 1 & 1.3 & 3 & - & 6 & 6 & 5 & 53 & - & 49 & 41 & 48 \\
\hline North-East Atlantic Zone fishing & 0 & 0 & 1 & 0 & 0.3 & - & - & 3 & - & 3 & - & - & 50 & - & 50 \\
\hline Jurisdiction comm./matters & 3 & 1 & 3 & 1 & 2.0 & 11 & 4 & 5 & 7 & 6.8 & 31 & 50 & 43 & 50 & 44 \\
\hline Dialogue common fisheries & 1 & 2 & 2 & 1 & 1.5 & 10 & 6 & 3 & 3 & 5.5 & 42 & 34 & 49 & 58 & 46 \\
\hline Bovine animals/swine & 0 & 0 & 1 & 1 & 0.5 & - & - & 5 & 5 & 5 & - & - & 46 & 45 & 46 \\
\hline Equal treatment employment & 1 & 2 & 3 & 1 & 1.8 & 11 & 4 & 8 & 7 & 7.5 & 31 & 40 & 35 & 34 & 35 \\
\hline Toys made of PVC & 3 & 3 & 3 & 1 & 2.5 & 10 & 12 & 8 & 8 & 9.5 & 33 & 31 & 41 & 39 & 36 \\
\hline Aggregate value ${ }^{2}$ & 24 & 24 & 39 & 21 & 108 & 220 & 155 & 230 & 169 & 774 & 39 & 40 & 40 & 44 & 41 \\
\hline
\end{tabular}

Notes: The official notation of these legislative proposals is, in descending order, as follows: COM (97) 358; COM (98) 295; COM (98) 320; COM (98) 461; COM (98) 546; COM (98) 586; COM (98) 623; COM (99) 130; COM (99) 260; COM (99) 345; COM (99) 348; COM (99) 382; COM (99) 456; COM (99) 565-7; COM (99) 577.

${ }^{1}$ Highest number of actors per issue taken in case the number of actors varies within a multi-issue proposal.

${ }^{2}$ The numbers stand for the sums per country and for all four countries together.

*TSE (Transmissible Spongiform Encephalopathy); **Eurodac (Européen Dactyloskopie - automated fingerprint identification system for asylum seekers and illegal immigrants). 
competence and availability of the prospective interview partners, to the four member states to conduct structured, in-depth élite interviews. The chosen experts identified first the controversial issues within a proposal and the actors who became active within the decision-making process. Our interview partners also had to locate the ideal points of the different stakeholders on each issue within a scale ranging from 0 to 100 and the final outcome of the decisionmaking process. If possible, they had to pinpoint the reference point (the outcome chosen in case the piece of legislation is not accepted) and the saliency each actor attributed to a proposal. To render the issues comparable, we normalized the actor positions, their power and the possible outcomes on the respective scales. ${ }^{6}$

As the systems of interest intermediation differ in the identification of the key players and their relative bargaining power, we have calculated different NBS models which take such divergences into account. Our approach distinguishes between the possibilities of a diverse set of actors to access the negotiations and the relative power they exert. We evaluate for each decision-making case the distance between the real outcome and the one that a specific model of interest intermediation predicts. To assess the general accuracy of a model, we mainly use the mean average distance between the outcome and the prediction as well as the number of times that a model provides more accurate forecasts in pairwise comparisons.

Among the models of interest intermediation, the pluralist NBS model is the most straightforward one. It assumes that the lead ministry in charge of the domestic pre-negotiations tries to strike a balance between the interests of all formal and informal groups who have become active in a decision-making process. Thus, the pluralist model that we test in the following contains the positions of all stakeholders on an issue. The consociationalist NBS, conversely, only refers to powerful interest groups which co-ordinate their positions on the contentious issues. The consociationalist model consequently only considers the positions of the most powerful actors left and right of the lead ministry, whereas the corporatist model also takes the position of this crucial government agent into account. The étatiste model of interest intermediation refers exclusively to the positions of the lead ministry and other participating state actors (Schneider and Baltz 2005). The clientelistic model, by constrast, takes the positions of the leading ministry and those stakeholders into consideration who are no more than a third of the maximum possible distance away from the initial position on the left or the right side of the initial position of the leading ministry. Hence, only close 'allies' of the agenda-setting state actor are considered to be relevant in this model.

Because our classification of systems of interest intermediation also considers power asymmetries between actors, we use the so-called asymmetric NBS. While the symmetric NBS assumes actors to be equally powerful (Nash 1950), its asymmetric counterpart takes exogenously given power differences into account (Schneider 2005). Substantively, the symmetric NBS predicts that the actors collectively choose a unique solution in the non-empty bargaining 
space $\Theta$. This solution is computed through the maximization of the product of the actors' utility functions $\mathrm{U}:{ }^{7}$

$$
S Y M . N B S=\max _{O \in \Theta} \prod_{i=1}^{n} U_{i}
$$

where $\mathrm{i}=1, \ldots, \mathrm{n}$ is the subscript for the stakeholders and

$$
U=D_{i}-\left|p o s_{i}-o\right|
$$

where $\operatorname{pos}_{i}\left(0 \leq \operatorname{pos}_{i} \leq 100\right)$ denotes the policy position of actor i and $D_{i}$ is its disagreement value, while $o$ is the negotiation outcome. Note that the utility function is constrained by the side condition of pareto efficiency $\left(U_{i} \geq 0\right.$ for all i). In general, the utility of actor $\mathrm{i}$ increases the smaller $\left|p o s_{i}-o\right|$ as compared to $D_{i}$.

The asymmetric NBS adds to this set-up the power differences between the participating actors as an exponent to the individual utility. Operationally, we use the power assessments of the expert interviews for this purpose. ${ }^{8}$ Formally, the asymmetric NBS amounts to:

$$
A S Y M \cdot N B S=\max _{O \in \Theta} \prod_{i=1}^{n} U_{i}^{p_{i}}
$$

where $p_{i}$ is the power of stakeholder $\mathrm{i}$.

Unlike the models presented in Bailer and Schneider (2006) and Schneider et al. (2006), we do not equate the disagreement value $D_{i}$ with the distance between the reference point (sq) and the actor's policy position (|sq-pos $\mid$ ) for two reasons. First, to rely on the reference point for the operationalization of the disagreement value would necessarily imply for most cases in our deterministic set-up, and under the side condition of pareto efficiency, that the outcome equals the reference point. Second, since players do not often share a common reference point, we cannot arbitrarily define one position as the disagreement value.

To avoid this indeterminacy, we use the standard assumption of bargaining models that all actors benefit from reaching a collective agreement. We therefore operationalize each player's disagreement value as a function of what she can expect to achieve without co-operation. The disagreement value reflects each player's capability to avoid the worst case scenario in case no agreement is reached; the capability in itself is assumed to be a function of each player's relative bargaining strength. ${ }^{9}$ The disagreement value is accordingly defined as 
Table 3 A three-player example of the model

\begin{tabular}{lcccccc}
\hline & Position & Power & $\begin{array}{c}\text { Distance to } \\
\text { worst case }\end{array}$ & $\begin{array}{c}\text { Disagreement } \\
\text { value }\end{array}$ & Outcome & $\begin{array}{c}\text { Utility of } \\
\text { bargain }\end{array}$ \\
\hline Player 1 & 20 & 0.33 & 80 & 53.3 & 40 & 33.3 \\
Player 2 & 25 & 0.33 & 75 & 50.0 & 40 & 35.0 \\
Player 3 & 70 & 0.33 & 70 & 46.7 & 40 & 16.7 \\
\hline
\end{tabular}

follows:

$$
D_{i}=\left(1-c_{i}\right) * g_{i}, \text { where } g_{i}=\left\{\begin{array}{l}
\text { pos }_{i} \text { if pos } \geq 50 \\
100-\text { pos }_{i} \text { if } \text { pos }_{i} \leq 50
\end{array}\right.
$$

with $c$ measuring the unilateral capability $\sum_{i=1}^{n} c_{i}=1$ ) of the respective stakeholder $\mathrm{i}$ and $g_{i}$ standing for the worst case scenario of this actor. Equation (4) implies for the extreme case that one player owns all power resources $(\mathrm{D}=0)$, that its policy position will be the collective outcome. In the other extreme of a completely powerless actor, the individual disagreement value equals the worst case scenario with $50<\mathrm{D}<100$. The subsequent calculations assume that all actors are equally capable of avoiding the worst outcome, therefore $c=1 / \mathrm{n}$.

Table 3 demonstrates the calculations with a simple three actor example. The three actors hold linear utility functions with ideal points situated at 20 , 25 and 70. The outcome that maximizes the NBS is at 40.

\section{PREDICTIVE ACCURACY OF THE INTEREST INTERMEDIATION MODELS}

In this section we evaluate the predictive accuracy of the competing models of interest intermediation for all issues in all four member states, using different evaluation criteria to assess the predictive accuracy of the bargaining models. Our unit of analysis remains the single issue because predictive errors tend not to cluster within the same proposal. ${ }^{10}$

The first measure we employ is the mean absolute error (MAE) of the predictions on each issue, which is a standard benchmark ranging from 0 (no error) to 100 (maximal error). Table 4 reports the MAEs of the seven different models for all issues and for each of the four member states alongside the maximum error of each model. Note that we do not include the asymmetric version of the corporatist and consociationalist models because their results do not differ significantly from those of the symmetric ones. ${ }^{11}$

As expected, the aggregate results show that the symmetric étatiste model fares best in comparison to all other models examined here; it provides, in other words, the most accurate forecasts. The corporatist model and the pluralist 
Table 4 Mean average error of the model predictions

\begin{tabular}{lcccccc}
\hline $\begin{array}{c}\text { NBS model of interest } \\
\text { intermediation }\end{array}$ & $\begin{array}{c}\text { All issues } \\
(n=108)\end{array}$ & D & Fin & NL & UK & $\begin{array}{c}\text { Max. } \\
\text { error }\end{array}$ \\
\hline Consociationalism & 40.16 & 30.58 & 32.46 & 51.91 & 38.1 & 100 \\
Corporatism & 14.37 & 17.29 & 15.41 & 15.18 & 8.02 & 84.9 \\
Symmetric/etatism & 12.95 & 17.66 & 15.42 & 13.31 & 4.95 & 70 \\
Symmetric/pluralism & 26.32 & 23.08 & 23.17 & 29.72 & 27.29 & 75.5 \\
Asymmetric/pluralism & 21.97 & 19.93 & 19.28 & 24.5 & 22.69 & 76.8 \\
Clientelism-right & 26.74 & 31.52 & 24.16 & 26.96 & 23.82 & 100 \\
Clientelism-left & 33.59 & 28.3 & 33.9 & 35.88 & 35.05 & 89.9 \\
\hline
\end{tabular}

Note: The clientelism-right model considers stakeholders to the right of the position of the leading ministry, the clientelism-left to the left.

model that takes the power asymmetries between the actors into account are ranked next to it. The symmetric pluralist model and one of the clientelistic models are situated in between, while the consociationalist model is at the bottom of the ranking. Comparing the two clientelistic models confirms that those stakeholders seem to win from the domestic bargainings which are more integration-prone than the lead ministry, since a higher value on the 100 -point preference scale indicates in most cases a more integration-prone attitude. The ranking between the two clientelistic models is only reversed in Germany. This means that the German ministry which is in charge of coordinating the domestic response to a Commission proposal is slightly more influenced by integration-sceptical groups than the 'agenda-setting' state actors in the other countries. This is also an indication of a particular political bias: because 'integration' often stands for consumer rather than producer friendly legislation, the German government often yields to the pressure exerted by business (Schneider and Baltz 2003).

It is, in our view, quite remarkable that the relative differences between the models are generalizable across all four member states under examination. Even in those countries purported to have a corporatist system of interest intermediation, the étatiste model offers on average the most precise forecasts. A detailed analysis of the agenda-setting capacity of the state actors confirms that the ministry formally in charge possesses considerable discretion during the domestic pre-negotiations across the four member states (Schneider and Baltz 2005).

As Bueno de Mesquita (2004) has recently argued, the MAE has, however, some shortcomings as a yardstick for the evaluation of policy models. It understates, for instance, the predictive error of a model as far as the maximum prediction error is a relevant consideration for predictive success. The MAE also does not take border or ceiling effects into account. We can therefore expect that the MAE correlates both negatively or positively with the number of alternative positions on an issue. If, for example, only the extreme positions of the issue continuum are occupied (0 and 100) and the prediction is at 50, 
Table 5 Pairwise comparison of model performance

\begin{tabular}{|c|c|c|c|c|c|}
\hline & All & $D$ & Fin & $N L$ & UK \\
\hline Corporatism v. consoc Nationalism & 69:19(19) & $12: 5(7)$ & $25: 10(4)$ & $15: 4(5)$ & $17: 0(3)$ \\
\hline $\begin{array}{l}\text { Corporatism v. clientelisme (right } \\
\text { of leading ministry (EM)) }\end{array}$ & 61:15 (31) & $18: 0(6)$ & $18: 10(11)$ & 12:4 (8) & 13:1 (6) \\
\hline Corporatism v. clienteısm (left of LM) & 74:30 (3) & $16: 8(0)$ & $22: 16(1)$ & 18:5 (1) & 18:1 (1) \\
\hline Corporatism v. symmetric pluralism & 63:39 (5) & $13: 11(0)$ & $19: 18(2)$ & $14: 7(3)$ & $17: 3(0)$ \\
\hline Corporatism v. asymmetric pluralism & 44:49 (14) & $8: 14(2)$ & $16: 21(2)$ & $8: 8(8)$ & 12:6 (2) \\
\hline Corporatism v. étatisme & $19: 24(64)$ & $3: 5(16)$ & $2: 13(24)$ & $5: 3(16)$ & $9: 3(8)$ \\
\hline Consociationalism v. clientelisme (right of LM) & $42: 50(15)$ & $12: 7(5)$ & $11: 24(4)$ & $9: 11(4)$ & $10: 8(2)$ \\
\hline Consociationalism v. clientelism (left of LM) & $48: 56(3)$ & $10: 14(0)$ & $10: 28(1)$ & $16: 7(1)$ & $12: 7(1)$ \\
\hline Consociationalism v. symmetric pluralism & $37: 68(2)$ & $7: 17(0)$ & $9: 29(1)$ & $10: 13(1)$ & $11: 9(0)$ \\
\hline Consociationalism v. asymmetric pluralism & $25: 77(5)$ & $5: 18(1)$ & $8: 30(1)$ & $7: 15(2)$ & $5: 14(1)$ \\
\hline Consociationalism v. étatisme & $25: 64(18)$ & $6: 11(7)$ & $5: 30(4)$ & $6: 14(4)$ & $8: 9(3)$ \\
\hline Clientelisme (right of LM) v. clientelisme (left of LM) & $56: 48(3)$ & $9: 15(0)$ & $21: 17(1)$ & $13: 10(1)$ & $13: 6(1)$ \\
\hline Clientelisme (right of LM) v. symmetric pluralism & $49: 58(0)$ & $6: 18(0)$ & $19: 20(0)$ & $11: 13(0)$ & $13: 7(0)$ \\
\hline Clientelisme (right of LM) v. asymmetric pluralism & $33: 71(3)$ & $3: 21(0)$ & $13: 26(0)$ & $9: 14(1)$ & $8: 10(2)$ \\
\hline Clientelisme (right of LM) v. étatisme & $17: 56(34)$ & $2: 16(6)$ & $10: 18(11)$ & $4: 11(9)$ & $1: 11(8)$ \\
\hline Clientelisme (left of LM) v. symmetric pluralism & $34: 72(1)$ & $8: 16(0)$ & $14: 25(0)$ & $6: 18(0)$ & $6: 13(1)$ \\
\hline Clientelisme (left of LM) v. asymmetric pluralism & $20: 85(2)$ & $6: 18(0)$ & $4: 35(0)$ & $6: 17(1)$ & $4: 15(1)$ \\
\hline Clientelisme (left of LM) v. étatisme & $27: 76(4)$ & $9: 15(0)$ & $12: 25(2)$ & $5: 18(1)$ & $1: 18(1)$ \\
\hline Symmetric pluralism v. asymmetric pluralism & $23: 63(21)$ & $5: 13(6)$ & $5: 25(9)$ & $8: 12(84)$ & $5: 13(2)$ \\
\hline Symmetric pluralism v. étatisme & $28: 74(5)$ & $9: 14(1)$ & $13: 24(2)$ & $8: 14(2)$ & $1: 19(0)$ \\
\hline Asymmetric pluralism v. étatisme & $41: 50(16)$ & 11:9(4) & $16: 21(2)$ & 9:7(8) & $5: 13(2)$ \\
\hline
\end{tabular}

Note: The entries read as the score of model A against model B with regard to the number of more accurate predictions; ties are in parentheses. Bold numbers stand for the model which has, in its category, been the best performing model six times; numbers in bold italics (italics) represent the event that a model was a winner in five (four) out of six pairwise comparisons. 
the maximum prediction error can be only 50 points. If more than two (extreme) positions are taken (for example, three at 0,75 , and 100 respectively) and the prediction is at 75 , the maximum error can be 25 (if the outcome is 100) or 75 (if the outcome is at the other extreme side of the preference scale).

In light of Achen's (2006) model evaluation strategy, we also compared the predictive accuracy across pairs of NBS interest intermediation models (Table 5). ${ }^{12}$ This second evaluation benchmark is used to assess the model performance in the aggregate as well as for each country under examination.

These results generally support the previous results. While the étatiste model of interest intermediation fares best across all countries, its corporatist counterpart outperforms it in the Netherlands and the United Kingdom. The asymmetric pluralist model is, according to this second evaluative criterion, the best model in Germany. Finland remains the only genuine étatiste country. While these Finnish and Dutch results are in line with the majority of the literature, they remain puzzling with regard to Germany and the United Kingdom. However, as far as the latter member state is concerned, the lead ministry rarely had to change its initial position, but if it has to do so, the positional change follows a corporatist rather than a pluralist logic. This means that in Great Britain state actors dominate the domestic bargaining processes that EU legislative proposals initiate. Great Britain also does not seem to be more pluralist than Germany or the Netherlands, which contradicts the textbook classifications of the systems of interest intermediation that supposedly prevail in these countries. ${ }^{13}$

\section{CONCLUSION}

In this paper we examined whether we can use the conventional classifications of the systems of interest intermediation for four member states of the EU to predict how the national bargaining position of the ministry negotiating at the Council level is domestically formed. Our inquiry contributes to the literature on EU policy-making and interest intermediation in several ways. First, our empirical analysis revealed that the pattern of interest intermediation in the domestic pre-negotiations is less clear-cut than assumed by the literature on systems of interest intermediation. The activation and coalition patterns among state and non-state actors vary so much across the different proposals that general typologies can only explain the domestic pre-negotiations to some extent. This supports the implicit impossibility thesis of Crombez (2002) and Freeman (1989) that almost no generalizations about interest intermediation are possible. Second, our analysis also underlines that state actors dominate the national negotiations on most issues. Yet, if non-state actors become involved, a corporatist understanding of the negotiations is much more helpful than a consociationalist one. As the empirical scope of this study is limited, we cannot judge whether actors would more frequently resort to consociationalist or pluralist interest intermediation in less controversial cases than the ones examined here. Third, the predictive success of the corporatist model depends heavily on the inclusion of state actors. This is a blow for the proponents of the thesis that the system of interest 
intermediation moves into an era where strong associations can counterbalance the national governments. Although governments have to respect the interests of their stakeholders to some extent, they possess ample and largely uncontrolled discretion in EU affairs. Last but not least, our analysis has also broken new ground by bringing the combination of formal models and systematic tests to the study of interest group behaviour in the EU. While the field is moving, as the other contributions to this special issue show, towards a systematic assessment of specific actor groups, it has up to now shied away from rigorously evaluating the extant classifications of interest intermediation. This paper shows that we can use applied game theory for this purpose.

Biographical notes: Gerald Schneider is Professor of Political Science in the Department of Politics and Management at the University of Konstanz, and Executive Editor of European Union Politics/Daniel Finke is a doctoral student at the Research Institute for Public Administration in Speyer/Konstantin Baltz is a doctoral student in the Department of Politics and Management at the University of Konstanz, and a Research Associate in the Department of Politics at the University of Greifswald.

Address for correspondence: Gerald Schneider, Department of Politics and Management, University of Konstanz, Box D 86, D-78457 Konstanz, Germany. Tel: +49-7531-88-3081/2608. Fax: +49-7531-88-2774. email: gerald.schneider@uni-konstanz.de

\section{ACKNOWLEDGEMENTS}

Previous versions of this paper have been presented at the Pan-European Conference on EU Politics, Bologna, June 2004, the Pan-European Conference on International Relations, The Hague, September 2004 and at seminars at the Free University of Amsterdam, Paris Science Po, and the Max Planck Institute in Cologne. We have received research support from the German Research Foundation and would like to thank Anette Arslantas, Ursula Klöpper, Christian Lau, Michael Weltin, and Carl Zimanky for their assistance. The source code for the calculation of the models, an illustrative case study and some additional material can be found on the replication homepage of the first author at: http:// www.uni-konstanz.de/FuF/Verwiss/GSchneider/downloads/daten.htm

\section{NOTES}

1 See also the discussion on the power of economic interest groups in Grossman (2004).

2 The overall rank out of 15 countries examined, the mean scores and the standard deviation of these four countries are as follows: Netherlands: 4th, 4.0, 1.0; Germany: 6th, 3.5, 0.9; Finland: 7th; 3.3, 1.0; United Kingdom 12th, 1.5, 0.8.

3 We acknowledge that none of the systems of interest intermediation studied here include EU-level actors. The exclusion of supranational institutions and 
intergovernmental bodies can, however, be justified through the agenda-setting power that the Commission most notably possesses. As the Commission introduces legislative proposals, it implicitly formulates the status quo position for the subsequent national debates.

4 For a similar classification, see Atkinson and Coleman (1989).

5 Schneider et al. (2006) use different versions of the NBS to assess the predictive accuracy of competing models of EU decision-making, in particular the interactions within the Council of Ministers.

6 These power and salience scales also range between 0 and 100 .

7 Similar to Schneider et al. (2006), we constrained the possible values of the optimization function to the bargaining space between 0 and 100 and we relied on the constrained optimization routine in GAUSS for the calculation of the optimized solution. We used the Newton algorithm as optimization method and employed the mean as the starting vector in all models. The mean was calculated from the positions of all national stakeholders on each issue of a proposal.

8 We use these power assessments for two purposes: first, we pre-select the actors included in the corporatist model based upon their attributed power and, second, we rely on this measure to calculate the asymmetric NBS models.

9 We owe this suggestion to James D. Fearon.

10 To control for possible problems of independence we calculated each issues probability to 'meet' another issue dominated by the same model in the entire dataset which amounts to values between 7.6 and 25.8 percent (depending on the predominant model of interest intermediation for that particular issue). As compared to these numbers, the average probability to 'meet' an issue of the same 'kind' within one proposal is 43.7 percent. Based on these results, we recalculated our results by averaging for proposal level first. The results do not change significantly. We therefore decided to keep the individual issue as our predominant level of analysis.

11 We have also conducted some sensitivity analyses to identify the factors that contribute to the forecasting error of the models. The main finding is that a polarization in the preferences of the actors exerts a strong influence on the accuracy of the predictions. Other measures of the preference distribution, like the variance or the skewness, are only significant for some models.

12 We also report in the webappendix to this article how frequently a model provided a 'point' prediction or was at least very close to the final outcome.

13 The results obtained by using the reference point differ only slightly: the best predictions still offer the étatiste model (MAE over all issues $=0.16$ ), followed closely by a clientelistic model taking only those actors on the right side of the position of the leading ministry into account $(\mathrm{MAE}=0.165)$ and the asymmetric pluralist model $(\mathrm{MAE}=0.21)$. The winners in this contest are followed by the clientelistic model with groups on the left side of the leading ministry (MAE $=0.23)$ and the symmetric pluralist model (MAE $=0.27$ ). The corporatist model still offers the worst predictions $(\mathrm{MAE}=0.29)$. Another and more direct comparison between the models is the number of times that one model forecast the outcome better than another one. We do not present the results from this prediction error measure because its results corroborate in general those gained by the MAE measure.

\section{REFERENCES}

Achen, C.H. (2006) 'Evaluating political decision-making models', in R. Thomson, F.N. Stokman, C. Achen and T. König (eds), The European Union Decides, Cambridge: Cambridge University Press, pp. 264-98.

Andersen, S.S. and Eliassen, K.A. (1993) Making Policy in Europe. The Europeification of National Policy-Making, London: Sage. 
Atkinson, M.M. and Coleman, W.D. (1989) 'Strong states and weak states: sectoral policy networks in advanced capitalist economies', British Journal of Political Science 19(1): 47-67.

Bailer, S. and Schneider, G. (2006) 'Schelling versus Putnam? The importance of constraints in European legislation', in R. Thomson, F.N. Stokman, C. Achen and T. König (eds), The European Union Decides, Cambridge: Cambridge University Press, pp. 153-77.

Bogaards, M. (2002) 'Consociational interpretations of the EU: a critical appraisal', European Union Politics 3(3): 357-70.

Bueno de Mesquita, B. (2004) 'Decision making models, rigor and new puzzles', European Union Politics 5(1): 134.

Crepaz, M. (2002) 'Norms, functions, and dialectics: the process of european integration - a reply to Bogaards', European Union Politics 3(3): 370-81.

Crombez, C. (2002) 'Information, lobbying and the legislative process in the European Union', European Union Politics 3(1): 7-32.

Eising, R. (2004) 'Multilevel governance and business interests in the European Union', Governance 17(2): 211-45.

Freeman, J. (1989) Democracy and Markets: The Politics of Mixed Economies, Ithaca, NY: Cornell University Press.

Gillingham, J. (1991) Coal, Steel, and the Rebirth of Europe, 1945-1955: The Germans and French from Ruhr Conflict to Economic Community, Cambridge: Cambridge University Press.

Gillingham, J. (2003) European Integration, 1950-2003: Superstate or New Market Economy?, Cambridge: Cambridge University Press.

Gorges, M.J. (1996) Euro-Corporatism? Interest Intermediation in the European Community, Lanham, MD: University Press of America.

Greenwood, J. and Aspinwall, M.D. (eds) (1998) Collective Action in the European Union: Interests and the New Politics of Associability, London: Routledge.

Greenwood, J. and Jordan, G. (1993) 'The United Kingdom: a changing kaleidoscope', in M.P.C.M. Van Schendelen (ed.), National Public and Private Lobbying, Dartmouth: Aldershot Press, pp. 65-90.

Grossman, E. (2004) 'Bringing politics back in: rethinking the role of economic interest groups in european integration', Journal of European Public Policy 11(4): $637-54$.

Grote, J. and Schmitter, P.C. (1999) 'The renaissance of national corporatism: unintended side-effect of european and monetary union or calculated response to the absence of european social policy?', Transfer 1(2): 34-63.

Haas, E.B. (1958) The Uniting of Europe: Political, Social, and Economic Forces 1950-1957, Stanford, CA: Stanford University Press.

Haas, E.B. (1964) Beyond the Nation-State: Functionalism and International Organization, Stanford, CA: Stanford University Press.

Katzenstein, P. (1985) Small States in World Markets: Industrial Policy in Europe, Ithaca, NY: Cornell University Press.

Lehmbruch, G. (1967) Proporzdemokratie: Politisches System und politische Kultur in der Schweiz und in Österreich, Tübingen: Mohr.

Lehmbruch, G. (1976) Parteienwettbewerb im Bundesstaat, Stuttgart: Kohlhammer.

Mazey, S. and Richardson, J. (eds) (1993) Lobbying in the European Community, Oxford: Oxford University Press.

Nash, J.F. (1950) 'The bargaining problem', Econometrica 18(2): 155-62.

Olson, M. (1965) The Logic of Collective Action: Public Goods and the Theory of Groups, Cambridge, MA: Harvard University Press.

Pedler, R. and Van Schendelen, M.P.C.M. (1994) Lobbying the European Union: Companies, Trade Associations and Interest Groups, Dartmouth: Aldershot Press. 
Sandholtz, W. and Zysman, J. (1989) '1992: recasting the European bargain', World Politics 42(1): 95-128.

Schmitter, P.C. (1974) 'Still the century of corporatism?', Review of Politics 36(1): 85-121.

Schneider, G. (2005) 'Capacity and concessions: bargaining power in multilateral negotiation', Millennium 33(3): 665-89.

Schneider, G. and Baltz, K. (2003) 'The power of specialization: how interest groups influence EU legislation', Rivista di Politica Economica XCIII(1-2): 253-83.

Schneider, G. and Baltz, K. (2005) 'Domesticated Eurocrats: bureaucratic discretion in the legislative pre-negotiations of the European Union', Acta Politica 40(1): 1-27.

Schneider, G., Finke, D. and Bailer, S. (2006) 'Bargaining power in the European Union. An evaluation of competing game-theoretic models', Fachbereich Politikund Verwaltungswissenschaft, Universität Konstanz.

Siaroff, A. (1999) 'Corporatism in 24 industrial democracies: meaning and measurement', European Journal of Political Research 36(2): 175-205.

Stokman, F.N. and Thomson, R. (eds) (2004) 'The winners and losers of European integration', Special Issue of European Union Politics 5(1).

Thomson, R., Stokman, F.N., Achen, C. and König, T. (2006) The European Union Decides, Cambridge: Cambridge University Press.

Traxler, F. and Knittel, B. (2000) 'The bargaining system and performance: a comparison of 18 OECD countries', Comparative Political Studies 33(9): 1154-90.

Traxler, F and Schmitter, P.C. (1995) 'The emerging euro-polity and organized interests'; European Journal of International Relations 1(2): 191-218.

Van Schendelen, M.P.C.M. (ed.) (1993) National Public and Private EC Lobbying, Dartmouth: Aldershot Press. 